\title{
О допустимых уровнях Т-2 токсина и его метаболитов в кормах (обзор)
}

Гогина Н.Н., старший научный сотрудник отдела физиологии и биохимии

ФГБНУ Федеральный научный центр «Всероссийский научно-исследовательский и технологический институт птицеводства» Российской академии наук (ФНЦ «ВНИТИП» РАН)

Аннотащия: Нормирование содержания микотоксинов 6 кормах ябляется актуальным бопросом. Проводимые анализы кормов и статистическая обработка полученных данных сбидетельствуют о значительной контаминации кормов, произбодимых на территории Российской Федерации, трихотеценовыми микотоксинами. Предельно допустимые концентрации, разработанные учеными и законодательно утвержденные, могут быть ориентиром, если бозникает необходимость использовать корма, содержащие Т-2 токсин и его метаболиты. В статье приведен обзор допустимых уровней Т-2 и НТ-2 токсинов 6 кормах, принятых В Российской Федерации и других странах.

Ключебые слова: Т-2 токсин, НТ-2 токсин, метаболиты, корм, предельно допустимая концентрация (ПДК).

Т-2 токсин является трихотеценом типа А, вырабатываемым плесневыми грибами Fusarium sporotrichioides, Fusarium poae и Fusarium acuinatum. Эти виды грибов также продуцируют НТ-2 токсин, моноацетоксисцирпенол, диацетоксисцирпенол, неосоланиол [1-3]. Плесневые грибы рода Fusarium поражают самые разные зерновые культуры и хорошо растут в холодных климатических зонах или при влажных условиях хранения зерна (оптимально при температуре $6-24^{0} \mathrm{C}$ и влажности выше 14\%). Плесневый гриб Fusarium обычно появляется на кончике колоса; как правило, он окрашен в белый цвет, но также сообщалось о розовых или красноватых формах [4]. Т-2 токсин является нелетучим, водорастворимым микотоксином, который обладает высокой устойчивостью к воздействию света и температуры. Метаболитами этого токсина являются НТ-2 токсин (продукт щелочного гидролиза), Т-2 тетраол, Т-2 триол, неосоланиол. Также имеются сообщения о нескольких гидроксилированных и деэпоксидированных метаболитах. Небольшая часть Т-2 токсина также метаболизируется в диацетоксисцирпенол и неосоланиол [5].

Т-2 токсикозы в легких случаях протекают в течение нескольких дней по типу гингивита, стоматита, глоссита, реже - по типу гастроэнтерита с тошнотой, рвотой и головокружением. При длительном потреблении токсичного корма у домашних животных (свиней, лошадей и птицы) токсикоз проявлялся в виде острого поражения желудочно-кишечного тракта, геморрагии и лейкопении $[6,7]$.

Т-2 токсин ингибирует синтез белка, РНК и ДНК. Сообщается о способности Т-2 токсина индуцировать апоптоз клеток, а в некоторых типах клеток вызывать некроз, а также перекисное окисление липидов, влияющее на цельность клеточной мембраны. Т-2 токсин индуцирует гематотоксичность и миелотоксичность, связанные с нарушением кроветворения В костном мозге $[8,9]$.

Согласно проводимым мониторинговым исследованиям, более 70\% кормов в России контаминированы трихотеценовыми мико- 
токсинами [10-13]. Поэтому подобрать «чистые» корма бывает весьма трудно.

В странах Европейского Союза существует понятие «переносимая суточная доза» токсина (tolerable daily intake, TDI). В результате исследований на группе свиней в 2004 г. TDI была установлена на уровне 0,1 мкг на килограмм массы тела в сутки для суммы Т-2 и НТ-2 токсинов. Но в 2017 г. этот норматив был понижен до 0,02 мкг/кг/сут. Аналогичные переносимые суточные дозы суммы Т-2 и НТ-2 токсинов установлены для домашней птицы. Значения для бройлеров составляют от 0,300,92 до 1,14-2,04; для курнесушек - от 0,31-0,85 до 1,081,82 ; для индюков на откорме - от 0, 1 8-0,39 до 0,6 1-0,97; для уток на откорме - от 0,20-0,59 до 0,46-1,27 мкг на килограмм массы тела в сутки [14-16].

Важным критерием в оценке качества кормов по безопасности является определение допустимой концентрации содержания микотоксинов в корме. Для оценки и предотвращения негативного воздействия токсинов, содержащихся в кормах, на сельскохозяйственных животных оперируют такими понятиями, как предельно допустимая концентрация (ПДК) или максимально допустимый уровень (МДУ) токсинов. ПДК - кон- центрация вещества в кормах (мг/кг, мкг/кг), которая в течение неограниченного продолжительного времени при ежедневном воздействии не вызывает отклонений в состоянии здоровья животных. МдУ - максимально допустимый уровень вещества (мг/кг, мкг/кг) или организма (шт./кг) в кормовом продукте или другом объекте.

О ситуации с нормированием микотоксинов в кормах В. Попов (2014) в своей статье сообщает, что, несмотря на важность проблемы и противоречивость мнений, в нашей стране не так много научно обоснованных и достоверных данных о безопасности кормов, содержащих различные виды и концентрации микотоксинов. Как все усредненные нормы, нормированные допустимые концентрации не являются абсолютными. Они зависят от вида, возраста, состояния, направления и уровня продуктивности животных и многих других факторов [17].

Сообщалось, что на основании собранных данных о течении заболевания, токсичности, обмену веществ у животных и клинических признаках токсикоза у домашней птицы было подсчитано, что общее количество всех трихотеценов, включая токсин Т-2, в корме для птиц не должно превышать 0,5 мг/кг [18].
Группой украинских и российских ученых в 1970-80 гг. были проведены масштабные исследования влияния Т-2 токсина на здоровье и продуктивность сельскохозяйственной птицы разных видов и возрастов. Было установлено, что наиболее чувствительными являются утки. Для индеек и гусей наименьшие концентрации Т-2 токсина в корме, вызывающие патологии, были в два раза выше. А для кур от 3-до 8-недельного возраста, получавших контаминированный корм в течение продолжительного периода, были установлены уровни наименьшего содержания Т-2 токсина в четыре раза выше, чем для уток [19].

В настоящее время в Российской Федерации существует ряд действующих документов, нормирующих содержание Т-2 микотоксина в кормах [20-24]. Содержание Т-2 токсина допустимо для кур-несушек, цыплят и птицы на откорме на уровне 0,1 мг/кг в комбикорме гранулированном, а также для яйценоской сельскохозяйственной птицы и дичи, цыплят, откармливаемой сельскохозяйственной птицы и взрослой дичи на уровне 0,1 мг/кг в крупке комбикормовой. Для крупного рогатого скота и свиней, выращиваемых на мясо для производства детского питания, ПДК также назначена на уровне 0,1 мг/кг корма. 
Технический регламент Таможенного союза ТР ТС $015 / 2011 \ll$ О безопасности зерна» нормирует содержание Т-2 токсина в злаковых культурах (пшеница, рожь, тритикале, овес, ячмень, просо, гречиха, рис, кукуруза, сорго), зернобобовых культурах (горох, люпин, бобы, вика, нут, чечевица, чина), масличных культурах (соя, рапс, подсолнечник) на уровне $0,1 \mathrm{мг/кг} \mathrm{[24].}$

Группой российских ученых в рамках проекта «ЭКОСИЛ» были разработаны «Рекомендации по микотоксикологическому контролю кормов для сельскохозяйственных животных и птицы» и утверждены Минсельхозом в октябре 2014 г. Согласно этим рекомендациям, в пшенице, ячмене, кукурузе, глютене, жмыхах и шротах, комбикормах для птицы и свиней ПДК составляет 0,1 мг/Кг. Но для цыплят до 90-суточного во3раста, бройлеров до 40-суточного возраста, кур-несушек, поросят до 4 месяцев жизни, супоросных и подсосных свиноматок ПДК предлагается понизить до 0,05 мг/кг.

В 2017 г. были опубликованы «Методические рекомендации по диагностике, профилактике и лечению микотоксикозов животных», разработанные группой российских ученых. Норматив содержания Т-2 токсина в кормах для продуктивной птицы (куры, утки, гуси, индейки, фазаны, перепела, страусы, цесарки) рекомендуется установить на уровне 0, 1 мг/кг. Но для цыплят в возрасте до 90 дней, бройлеров в возрасте до 30 дней, утят в возрасте до 55 дней, гусят в возрасте до 65 дней, индюшат в возрасте до 60 дней и курнесушек предлагается понизить норму до 0,05 мг/кг. Также впервые рекомендовано обратить внимание на содержание НТ-2 токсина и ориентироваться на сумму Т-2 токсина и НТ-2 токсина. Рекомендуемые ПДК для этой суммы заданы на уровне 0,1 и 0,05 мг/кг соответственно [25].

МДУ для Т-2 и НТ-2 токсинов в зерновых и полнорационных кормах сильно различаются между странами в мировом пространстве $[26,27]$. Так как данных о токсикокинетике и биологическом воздействии Т-2 и НТ-2 токсинов пока собрано недостаточно, не установлено специфических правил или рекомендаций Европейской Комиссии о максимальных концентрациях этих токсинов в продуктах, предназначенных для кормления животных. Некоторые другие страны установили свои ориентировочные значения для Т-2 токсина в кормах. На Украине эти уровни для всех трихотеценов составляют 0,2 мг/ кг в комбикорме для несушек и бройлеров, 0,25 мг/кг в кормах для телят и крупно- го рогатого скота мясного направления. В Сербии и Черногории 0,3 мг/кг в корме для цыплят и 0,6 мг/кг в корме для свиней, крупного рогатого скота и для другой домашней птицы. В Китае предел Т-2 токсина в комбикормах для всех животных составляет 0,08 мг/кг. Предел 0,1 мг/кг для токсина Т-2 был установлен в Израиле для зерновых и в Иране для комбикормов для мелкого рогатого скота и мясного крупного рогатого скота. В комбикормах для телят, ягнят, молочных овец, коз и крупного рогатого скота в Иране ПДК Т2 токсина - 0,025 мг/кг. В Канаде корм для свиней и птицы может содержать до 0,1 мг/кг Т-2 токсина, а также регламентировано содержание НТ-2 токсина в этих же кормах - 0,1 мг/кг. В Хорватии МдУ Т-2 токсина, включая его метаболит НТ-2 токсин, в полнорационных кормах для свиней, птицы и телят составляет 0,5 мг/кг [18].

Обзор имеющихся данных о нормировании содержания Т-2 токсина и его метаболитов в кормах свидетельствует об актуальности вопроса и необходимости дальнейших исследований и разработок. С развитием научных знаний о метаболизме и токсикокинетике трихотеценовых микотоксинов, а также методов их обнаружения в кормах, возможно установление более точных ПДК для Т-2 
токсина и его метаболитов.

\section{Литература}

1. Фисинин В.И. Микотоксины и антиоксиданты: непримиримая борьба (Т-2 токсин - метаболизм и токсичность) / Фисинин В.И., Сурай П.// Птица и птицепродукты.- 2012. - № 3. - С. 38-41.

2. Шамрай С.М. Микотоксины - постоянная угроза со стороны «экологически чистых» природных ядов // Биология: все для учителя. Пилотный выпуск.- 2010. С. 7-14.

3. Diaz D.E. The Mycotoxin Blue Book. Nottingham University Press, 2005.P.349.

4. Yli-Mattila T. Fusarium sibiricum sp. nov, a novel type A trichotheceneproducing Fusarium from northern Asia closely related to F. sporotrichioides and F. langsethiae./ Yli-Mattila T., Ward T.J., O'Donnell K., Proctor R.H., Burkin A.A. [et al.] // Food Microbiol. - 2011. - V. 147. - P. 5868.

5. Li Y. T-2 Toxin, a trichothecene mycotoxin: Review of toxicity, metabolism, and analytical methods / $\mathrm{Li}$ Y., Wang Z., Beier R.C., Shen J., De Saeger S., Zhang S. // J. Agric. Food Chem. 2011. - V. 59, No 8 - P. 3441-3453.

6. Иванов А.В. Микотоксикозы (биологические и ветеринарные аспекты) / А.В. Иванов, В.И. Фисинин, М.Я. Тремасов, К.Х. Папуниди. - М.: Колос, 2010. 392 c.

7. Иванов А.В. Микотоксины (в пищевой цепи) / А.В. Иванов, В.И. Фисинин, М.Я. Тремасов, К.Х. Папуниди. - М.: ФГБНУ «Росинформагротех», 2012. -
C. 136 .

8. Schlatter J. Toxicity data relevant for hazard characterization // Toxicol. Lett. - 2004. - V. 153. - P. 8389.

9. Диаз Д. Микотоксины и микотоксикозы. - М.: Печатный Город, 2006. - 382 с.

10. Гогина Н.Н. Мониторинг содержания микотоксинов в кормах средней полосы Российской Федерации за 20152016 годы / Гогина Н.Н., Круглова Л.М., Кожаринова Ю.С. // Мировые и российские тренды развития птицеводства: реалии и вызовы будущего. Мат. XIX Междунар. конф. Рос. отд. ВНАП. - Сергиев Посад: ВНИТИП, 2018.

-C. 181-183.

11. Джатдоева А.А. Исследование загрязненности микотоксинами кормов и кормового сырья на территории Российской Федерации / Джатдоева А.А., Селимов Р.Н., Грачева Т.С., Метальников П.С., Комаров А.А.// Успехи мед. микол. - 2018. - Т. 19. Гл. 9. - C. 297-298.

12. Кононенко Г.П. Фузариотоксины в зерновых кормах / Кононенко Г.П., Буркин А.А. // Вет. патология. - 2002. № 2.- C. 128-132.

13. Седова И.Б. Анализ результатов мониторинга загрязнения микотоксинами продовольственного зерна урожаев 2005-2016 гг. / Седова И.Б., Киселева М.Г., Чалый 3.А., Аксенов И.В., Захарова Л.П., Тутельян В.А. // Успехи мед. микол. - 2018.- Т. 19. - С. 329-330.

14. EFSA Panel on Contaminants in the Food Chain (CONTAM); Scientific opinion on the risks for animal and public health related to the presence of $\mathrm{T}-2$ and $\mathrm{HT}-2$ toxins in food and feed // EFSA J. - 2011. -V. 9, No 12. - P. 24-81.

15. Arcella D. Scientific report on human and animal dietary exposure to T-2 and HT-2 toxins / Arcella D., Gergelova P., Innocenti M.L., Steinkellner H. // EFSAJ. 2017. - V. 15, No 8. - 57 pp.

16. Report on toxicity data on trichothecene mycotoxins HT-2 and T-2 toxins / Schuhmacher-Wolz U., Heine K., Schneider K.// EFSA J. - 2010 0. - V. 7. P. 57.

17. Попов В. Каким ПДК верить? // Аграрное обозрение. - 2014. - № 2 - С. 46-50.

18. Eriksen G.S. Toxicological evaluation of trichothecenes in animal feed / Eriksen G.S., Pettersson H. // Anim. Feed Sci. Technol. - 2004. - V. 114. - P. 205-239.

19. Мікотоксикози птиці: етіологія, діагностика, профілактичні засоби і методи (результати 33-річних досліджень). Під редакціэю доктора ветеринарних наук Котика А.М. і кандидата біологічних наук Труфановоп В.О. - Харків, 2005. - 124 c.

20. ГОСТ Р 51899-2002. Комбикорма гранулированные. Общие технические условия (с поправкой). - М.: Стандартинформ, 2008.- 9 c.

21. ГОСТ Р 54379-2011. Крупка комбикормовая. Технические условия - М.: Стандартинформ, 2012. - 10 с.

22. ГОСТ 32855-2014. Требования при выращивании и откорме молодняка крупного рогатого скота на мясо 
для выработки продуктов детского

питания. Типовой технологический процесс. - М.: Стандартинформ, 2015. $-10 \mathrm{c}$.

23. ГОСТ 33867-2016. Требования при выращивании и откорме свиней на мясо для выработки продуктов детского питания. Типовой технологический процесс. - М.: Стандартинформ, 2018. -8 c.

24. Технический регламент Таможен- ного Союза ТР ТС015/2011 «О безопасности зерна» от 9 декабря 2011 г. № 874 (с изменениями на 15 сентября 2017 г.). - ИС «Техэксперт: 6 поколение». - 31 с.

25. Методические рекомендации по диагностике, профилактике и лечению микотоксикозов животных. - М.: ФГБНУ «Росинформагротех», 2017.- 68 с.

26. Anukul N. Significance of regulation limits in mycotoxin contamination in
Asia and risk management programs at the national level / Anukul N., Vangnai K., Mahakarnchanakul W. // J. Food Drug Anal.-2013. - V. 21, No 3.- P. 227-241. 27. Sokolovi M. T-2 toxin incidence and toxicity in poultry / M. Sokolovi, V. GarajVrhovac, B. Impraga // Arch. Hig. Rada Toksikol. - 2008. - V. 59. - P.43-52.

Для контакта с автором:

Гогина Надежда Николаевна

E-mail: n.n.gogina@mail.ru

\title{
Tolerable Concentrations of T-2 Toxin and Its Metabolites in Feeds: A Review
}

\author{
Gogina N.N.
}

Federal Scientific Center "All-Russian Research and Technological Institute of Poultry" of Russian Academy of Sciences

Summary: The control of the concentrations of mycotoxins in feeds and feedstuffs is an urgent problem of animal mycotoxicology. The analyses of feeds produced in the Russian Federation and statistical analysis of the data obtained evidenced the significant contamination of feeds with trichotecene mycotoxins. If there is a need to use the feeds containing T-2 toxin and its metabolites the maximal tolerable concentrations or tolerable daily intakes (TDIs) developed by the scientists and legislatively approved can be used as reference values. The tolerable concentrations of T-2 and HT2 toxins in feeds approved in Russian Federation and foreign countries are reviewed.

Key words: T-2 toxin, HT-2 toxin, metabolites, feeds, maximal tolerable concentration.

ОТРАСЛЕВЫЕ НОВОСТИ

\section{Вспьики птичьего гриипа зафиксированы 6 Саудовской АраВии.}

Ранее б Китае сообщили о бспышке птичьего гриппа на ферме рядом с Уханем.

Вспыики высокопатогенного птичьего гриппа двух типов зафиксированы в Саудовской Аравии и во Вьетнаме, coобщ,aеm Reuters со ссылкой на Всемирную организацию по охране здоровья животных (OIE). В двух странах погибли почти 25 тысяч птиц.

По данным Министерства сельского хозяйства Саудовской Аравии, на птицеферме б иентральной части королебства Судаира погибли 22700 птии. Кроме того, по решению бластей были забиты 385 тысяч птии. Там зарегистрирован Высокопатогенный тип птичьего вируса H5N8.

Источник: informburo.kz 